Shala Barczewska

Jan Kochanowski University in Kielce

Paulina Barańska

Jan Kochanowski University in Kielce

\title{
IMAGINING THE END OF THE WORLD: POLISH PERSPECTIVES
}

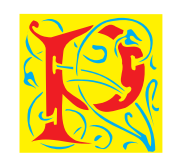

redictions regarding the end of the world are not new; however, they do seem to be increasing in frequency. As of July 10, 2016, Wikipedia lists 172 doomsday predictions from 66 B.C. to the present, with 61 in the 20th century and 31 from 2000 onward. An alternative website, Rationalwiki, lists 67 predictions during the 20th and 21st centuries, several of which differ from Wikipedia. A few of the apocalyptic predictions listed on these websites include those of the Jehovah's Witnesses (1914, 1915, 1918, 1920, 1925, 1941, 1975, 1997), Jim Jones (1967, 1978), Heaven's Gate (1997), Y2K (January 1, 2000), Harrold Camping (September 6, 29 and October 2, 1994; March 31, 1995; May 21 and October 21, 2011), the end of the Mayan calendar (December 21, 2012), and John Hagee and Mark Biltz's Blood Moon Prophecy (April 2014 - September 2015). The fact that both Jim Jones' movement and Heaven's Gate ended in mass murder-suicides demonstrates the level of fear and desperation evoked by doomsday prophecies, as well as the power held by their promoters. This phenomenon provides many areas for research. What is more, thanks to the Internet and various forms of social media, these once local apocalypses are quickly shared across the international community, thereby eliciting, if not outright demanding, a response.

In this paper, we focus on how Polish-speaking people cope with this heightened state of uncertainty through the creation and propagation of internet memes. Specifically, we look at Polish image macros and demotivators as 
a window into understanding how this online community responded to 2011 and 2012 doomsday predictions. These dates were chosen because of the different motivation behind them: Camping claimed biblical inspiration for his dates of May 21 and October 21, 2011, whereas the December 21, 2012 apocalypse coincided with the end of the Mayan calendar and received scientific as well as popular responses.

We begin by providing some elements of Polish culture that may have influenced Poles' attitudes to these predictions. Then we explain what internet memes are and why they provide a valid and perhaps even ideal medium for exploring responses to the anxiety or uncertainty caused by these doomsday premonitions. This is followed by a description of the method used for gathering and classifying the memes. The results section presents the responses exhibited in the memes for both time frames. The discussion summarizes the results and offers suggestions for future research.

\section{Polish cultural elements}

The cultural and historical complexity of Poland makes it difficult to hypothesize responses to these apocalyptic potentialities. On one hand, there are several reasons to expect Poles to ignore them. Polish people score moderately when it comes to being future-oriented; that is, they tend to deal with issues as they arise rather than plan ahead. ${ }^{1}$ Furthermore, the communist past encouraged scepticism and distrust, particularly as regards popular media. ${ }^{2}$ In terms of religion, citizens are largely Roman Catholic, which provides believers with an alternative end-of-the-world scenario as well as suggestions on how to best prepare spiritually. However, there are also reasons to believe that Poles' curiosity, and perhaps anxiety, would be awakened by the predictions. Despite the strong position of the Roman Catholic Church, the population is largely superstitious; for example, a significant number of Poles believe in the relevance of the zodiac. ${ }^{3}$ At the same time, Polish people often turn to experts for answers to

\footnotetext{
${ }^{1}$ L. Kolman et al., "Cross-cultural differences in Central Europe," Journal of Managerial Psychology 18:1 (2003), doi:10.1108/02683940310459600.

2 P. Sztompka, "The ambivalence of social change. Triumph or trauma?," WZB Discussion Paper, P 00-001 (2000).

3 E. Krajewska-Kułak et al., "Current view of the traditional superstitions in general population of Podlaskie province. Preliminary study," Progress in Health Sciences 1:2 (2011).
} 
questions or to learn about exotic cultures and alternative or hidden wisdom. ${ }^{4}$ Channels such as Discovery and National Geographic are popular and many of the articles covering the Mayan apocalypse were published in the scientific sections of newspapers and magazines. ${ }^{5}$

\section{Internet memes and image macros}

To understand what memes are, it is necessary to begin with the definition provided by Richard Dawkins, who coined the term in 1976 in an attempt to describe cultural transmission as a natural and evolutionary process. According to Dawkins, the noun meme is "conveys the idea of a unit of cultural transmission, or a unit of imitation. [...] Examples of memes are tunes, ideas, catch-phrases, clothes fashions, ways of making pots or of building arches. $[\ldots]$ memes propagate themselves [...] by leaping from brain to brain via a process which, in the broad sense, can be called imitation." 6 The resulting field of mimetics has been both applauded and criticized by scholars of various disciplines. ${ }^{7}$

As communication via the internet increased, this term was borrowed or, as Dawkins puts it, "hijacked", to describe what Davidson defines as a "piece of culture, typically a joke, which gains influence through online transmission." More recently, Börzsei has argued that this definition is overly simplistic, if not outdated. Instead, she follows the internet database "Know Your Meme" in arguing that an internet meme is identified by the fact that it is changed and adapted as it is passed from person to person. ${ }^{9}$ This project follows previous

${ }^{4}$ L. Kolman et al., "Cross-cultural differences in Central Europe"...

5 “Co oglądają Polacy" [What Poles are watching], portalmedialny.pl, 16.01.06, http:// mediafm.net/art/32076/co-ogladaja-polacy.html.

${ }^{6}$ R. Dawkins, The selfish gene, 30th anniversary ed., Oxford, New York: Oxford University Press, [1976] 2006, 192.

7 E.g., P. Chilton, "Manipulation," in: Discursive Pragmatics, ed. J. Zienkowski, J.-O. Östman and J. Verschueren, Vol. 8, Amsterdam: John Benjamins, 2011, 176-89.

8 R. Dawkins, Saatchi \& Saatchi New Directors' Showcase, Cannes, 2013. https://www. youtube.com/watch?v=GFn-ixX9edg; P. Davidson, "The Language of Internet Memes," in: The social media reader, ed. M. Mandiberg, New York: New York University Press, 2012, $120-134,122$.

9 L. K. Börzsei, "Makes a Meme Instead: A Concise History of Internet Memes," New Media Studies Magazine 7 (2013), 4. 
work by Börzsei, Dynel, and Piekot and focuses on online image macros and demotivators as examples of internet memes. ${ }^{10}$

Image macros were chosen because of their joke-like structure and because humour plays an important role in coping with anxiety and uncertainty. ${ }^{11}$ Moreover, they have been recognized as a valid modality of communication for a variety of reasons. Firstly, internet memes exemplify contemporary language in use and comprise both a genre and "a part of vocabulary for Internet users." ${ }^{2}$ Secondly, because internet memes "have to be really well suited to their environment $[\ldots]$ the cultural zeitgeist," in order for them to not only pass from user to user but to also be changed and modified, they can be viewed as a form of internet discourse that is representative of online users. ${ }^{13}$ Thirdly, they contain a number of elements-film scenes, cultural and historical events and personalities, idiomatic phrases — and their intertextual nature provides a broad representation of how members of society view and interact with these cultural icons. ${ }^{14}$ Because internet meme creation and propagation is both participatory and culturally relevant, it is the ideal medium for analysing a community's response to a threat or event, such as the apocalypse. For these reasons, it is believed that this form of intertextual communication will provide valuable insight into Polish perceptions of these doomsday warnings.

\section{Method of data collection}

May 1 - October 31, 2011, and December 1-31, 2012, were the time frames chosen for analysis. This was intended to provide a contrast between Camping's 2011 predictions regarding Jesus' imminent return, first on May 21

${ }^{10}$ M. Dynel, “'I Has Seen Image Macros!' Advice Animal Memes as Visual-Verbal Jokes,” International Journal of Communication 10, (feature) (2016). T. Piekot, "Pictorial representation of idioms in Internet humour," in: Estonia and Poland: Creativity and tradition in cultural communication, ed. L. Laineste, D. Brzozowska and W. Chłopicki, Vol. 1: Jokes and their relations, v.2, Tartu: ELM Scholarly Press; Eesti Kirjandusmuuseumi Teaduskirjastus, 2012.

${ }^{11}$ M. Dynel, “'I Has Seen Image Macros!' Advice Animal Memes as Visual-Verbal Jokes”...; N. A. Kuiper et al., "Humor Styles and the Intolerance of Uncertainty Model of Generalized Anxiety," Europés Journal of Psychology 10, nr 3 (2014), doi:10.5964/ejop.v10i3.752.

12 L. Börzsei, "Makes a Meme Instead: A Concise History of Internet Memes"... 24.

13 Don Caldwell, quoted in Sam Leith, "What does it all meme?," Financial Times, 14.10.11, http:/www.ft.com/intl/cms/s/2/027fefe6-f4b7-11e0-a286-00144feab49a.html.

${ }_{14}$ T. Piekot, "Pictorial representation of idioms in Internet humour"... 
and then on October 21, and predictions corresponding with the end of Mayan calendar on December 21, 2012, and at times connected with Nostradamus. The image macros were found using Google search and the terms koniecswiatal koniecświata (memy) [end of the world (memes)] for the two periods. Polish meme-creating websites were also visited, but their search engines were not able to pull up as many results as Google. ${ }^{15}$ Each image macro was marked for the attitude it presented. For some memes, more than one response was marked. For example, memes featuring politicians were marked both "political" and according to the perspective conveyed. The categories used were derived from the content of the memes rather than prescribed in advance. Moreover, the memes and their categories were discussed and agreed upon by both researchers (American and Polish) to decrease personal and cultural biases. Once the memes were categorized, metacategories (themes) were chosen to help organize and summarize the results. The graphs in the results section depict the total number of perspectives/responses identified in the memes.

It must be added that each search conducted on Google brings up similar, albeit slightly different results, which differ from day to day as well as computer to computer. For this reason, we look at the numbers given in the graphs as representative rather than absolute, and as a guide for understanding the Polish online community's responses to end times predictions.

\section{Results}

As mentioned above, the memes were categorized according to the perspective(s) or attitude(s) they conveyed regarding Camping's end-of-theworld predictions in 2011 and the end of the Mayan calendar in 2012. Twenty-nine memes were included in the 2011 analysis; 132 memes in the 2012 analysis. ${ }^{16}$ Some memes exhibited more than one response to a given prediction, thus the total number of responses in the graphs below exceed the number of memes analysed.

15 http://memy.pl; http://demotywatory.pl/; http://fabrykamemow.pl/. Only those images/cartoons that had been modified by internet users were included in the analysis.

16 This discrepancy suggests less interest in the 2011 predictions made by a foreign (American) pastor than the end of a calendar of an ancient and foreign (Mayan) civilization. It would be an interesting issue for further research; however, it falls outside the scope of the current project. 


\section{Camping's 2011 predictions}

Camping was trained as a civil engineer and was a self-made millionaire by age 35 . In 1959, after years of in-depth Bible study, he began broadcasting his religious views. One of his key interests was numerology and calculating the world's end. Although he began making predictions as early as 1970, his 2011 predictions received the most publicity, resulting in both an increase in followers, on one hand, and ridicule, on the other. They also proved to be the costliest with 5,000 billboard warnings, not to mention printed materials in as many as 75 languages, paid for by his listeners. ${ }^{17}$ Followers also quit jobs, sold possessions and travelled to convince fellow citizens to prepare for Jesus' return. While the date was well publicized in the U.S., it seems to have made only a small impact on Polish internet society. Only twenty-nine image macros were found. The graph in Figure 1 highlights the responses to the predictions as expressed in the image macros analysed.

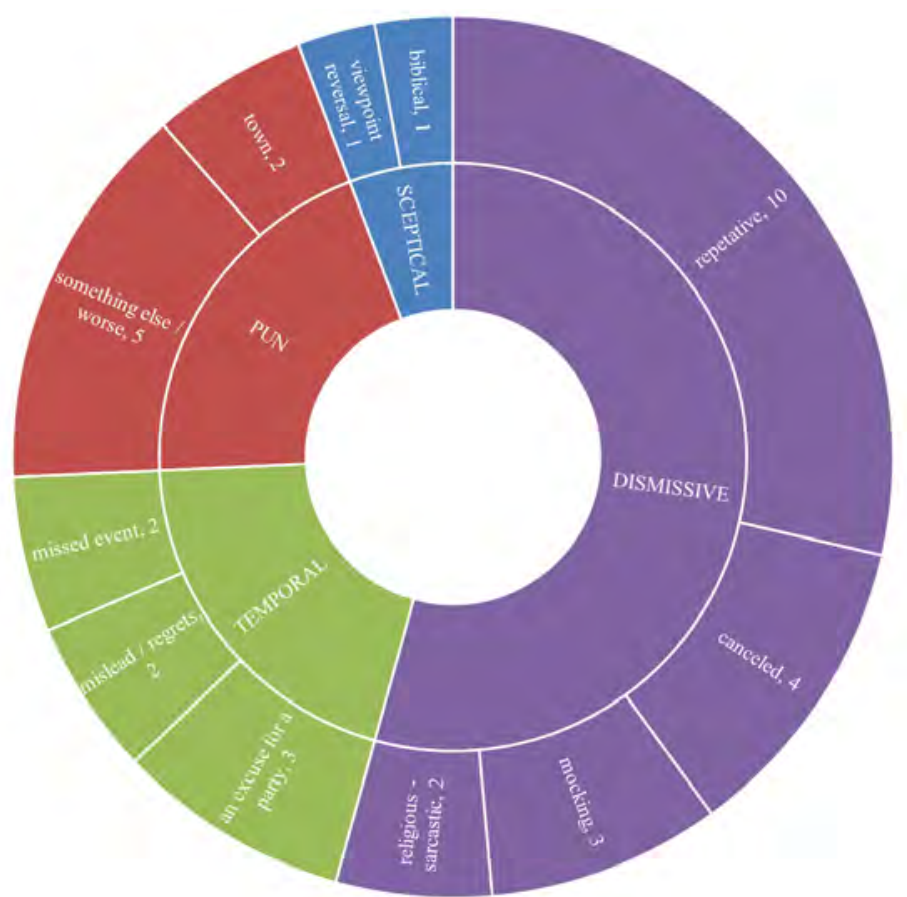

Figure 1. Memes in 2011

\footnotetext{
17 http://www.nytimes.com/2013/12/18/us/harold-camping-radio-entrepreneur-whopredicted-worlds-end-dies-at-92.html?_r=0.
} 
The image macros cast doubt onto the validity of Camping's predictions. The scepticalmetacategory includes "biblical" and "viewpoint reversal" memes. The former contrasts Camping's predictions with what the Bible says about the apocalypse, namely, that we will not know the day or hour. The latter reminds the reader or viewer that, one way or another, the end of the world will occur for each of us as we all must face death.

Those in the punsmetacategory rely on a play on words for their humorous response. In two demotivators, the Polish village KoniecŚwiata [end of the world] is presented as an alternative interpretation, making a trip there the best opportunity this generation has of experiencing the world's end. Other memes use "the end of the world" as a hyperbole and suggest an alternative event that they find equally as shocking or devastating, such as Mondays or waking up at Gam on a Saturday to watch the apocalypse (not) unfold. One of these memes, the text of which can be translated The end of the world didn't come, but something much worse is getting closer: / Monday / End of the World / In demo version each week, appears in both 2011 and 2012 datasets.

Temporal memes focus on enjoying the here and now. Some of these express frustration with the fact that both dates predicted by Camping fall on the weekend: should one of his predictions be accurate, weekend plans would be ruined. Alternatively, if the predictions fail, the party will continue and so will life, which could lead to disastrous consequences for those who behaved as if they could enjoy a life free of consequences.

Dismissive is the largest metacategory. It includes memes that mock those who accepted the predictions, suggest the apocalypse is easily cancelled by a notice on Facebook or a movie star, or reassure viewers that since they have survived so many end-of-the-world predictions, they will likely survive this one as well.

Within this set of memes, it is interesting to see how religious issues were (not) addressed. Several of the demotivators include pictures of Camping's billboards and van, which encouraged the passer-by to repent and make himself/ herself right with God. However, none of the commentaries provided by the internet users made reference to this aspect of preparing for the apocalypse. The focus instead was on using the billboard as a backdrop for creating a humorous or sarcastic response. Another meme completely deviated from the biblical narrative prompted by Camping's prediction. It depicted God or Jesus as a representative of the Barcelona football team arm-wrestling the devil, identified with Manchester United. Not only could this image itself be viewed as sacrilegious, but also its presupposition, i.e., that the devil, rather than God, decides when the world ends. 


\section{December 21, 2012, and the Mayan calendar}

The end of the Mayan calendar on December21, 2012 was believed to signal a cataclysmic end of the world. This opened the door to a number of speculations, discussed in both scientific and popular culture sections of Polish newspapers. The internet memes addressing these doomsday predictions are much more numerous and much more varied than those developed in response to Camping's predictions. The graph in Figure 2 presents the diversity of these responses.

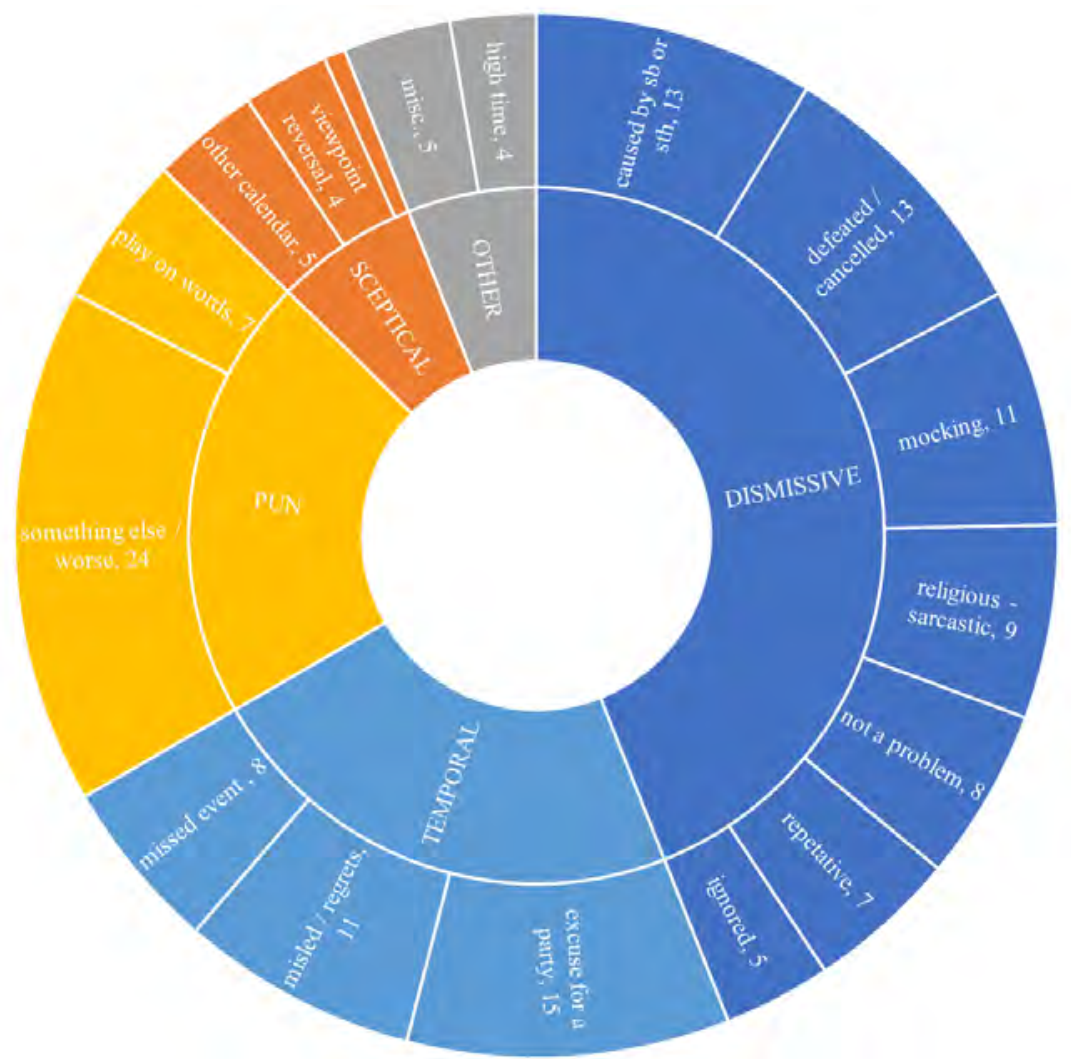

Figure 2. 2012 memes

In general, the memes did not seem to take the threat seriously. The majority are dismissive and fall on a continuum from simply ignoring the whole event with the phrase "nieobchodze" [I don't celebrate] to mock those who acted on the prediction. Within this metacategory there were several memes in which famous personalities were blamed for or took responsibility for causing, 
cancelling, or defeating the doomsday threat: Vladimir Putin, Chuck Norris, MacGyver, and Radom's "Chytra baba" (Stingy woman). ${ }^{18}$ Some of these, along with others, took advantage of the opportunity to comment on political or social issues. For example, several of the politically motivated image macros criticized then Prime Minister Donald Tusk and/or his party's fiscal policy.

Creators of image macros also focused on the temporal. These memes discussed upcoming events— such as plans for Christmas or New Years—and how these would be missed or changed. For example, one meme used the Mayan prediction to explain an early showing of the movie Home Alone, affectionately referred to in Poland as "Kevin", which has become a Christmas Eve tradition. Others saw the impending apocalypse as an excuse to party. Assuming the reckless attitude that the end of the world can inspire, others mocked those who, believing the end was near, did something that otherwise would have been foolish.

Wordplay is also more frequent and varied. Examples include With their calendar the Mayans taught us, that if you don't finish something... it's not yet the end of the world, as well as "Mayan" Mayans_end of the world in December I 'Decemberians - end of the world in May! (Figure 5). Another creative meme template suggested that Gangnam Style dance of the Korean band PSY was actually the fulfilment of Nostradamus' prophecy. These memes claimed the dance's popularity either portended the end of the world or gave reason to hope it would come quickly. This was an example of a meme borrowed from an English-speaking culture, cut and pasted, untranslated, into a Polish frame.

Sceptical covers three responses. One, using the "philosoraptor" template, questions the accuracy of the Mayan prediction against the Bible. The others either focus on each person's individual apocalypse/death or, as a deviation from the 2011 memes, suggest other calendars, such as those on one's mobile phone, could be alternative portenders of the world's end.

\section{Discussion and suggestions for future research}

Polish internet meme creators did not seem to take any of apocalyptic scenarios studied here seriously. While Camping's predictions appear to have been largely ignored by Polish internet users, those that did address them were

18 In the 2012 data, thirteen memes included at least one politician, nine included another well-known Polish personality, and thirty-one were based on foreign personalities or cartoon characters. 
sceptical. One response that is visible in the 2012 data, but absent from 2011, is the notion that the end of the world would be a good thing. Apart from this, the image macros could be placed into the same metacategories. However, the 2011 memes did not offer the cultural or political alternatives present in the 2012 memes. The reasons for these differences are unclear. One possibility is that the religious nature of the predictions controlled the responses, another is that the event did not receive enough coverage.

This paper presents only the beginnings of what promises to be an interesting study into Polish responses to doomsday warnings. Further analysis could include a comparison of news articles and readers' online comments to see to what extent they coincide with the opinions expressed in the memes. Alternatively, a project could look at doomsday memes of other cultures and language groups.

Moreover, this also shows potential for future research into the cognitive mechanisms involved in the creation and transfer of memes. What elements of shared knowledge are presupposed in meme creation or required for their interpretation? How does the speech act of an image macro frame interact with new super-imposed lexical content? Answers to these questions would improve our understanding of the processes of conceptual blending and the transfer/ translation of cultural elements.

\section{References}

Börzsei, L., "Makes a Meme Instead: A Concise History of Internet Memes," New Media Studies Magazine 7, 2013, 152-191.

Chilton, P., "Manipulation,” Discursive Pragmatics, ed. J. Zienkowski, J.-O. Östman and J. Verschueren, Vol. 8, Amsterdam: John Benjamins, 2011, 176-89.

Coldwell, W., "Dark tourism: why murder sites and disaster zones are proving popular," The Guardian, October 31, 2013, https://www.theguardian.com/travel/2013/oct/31/ dark-tourism-murder-sites-disaster-zones (March 23, 2016).

Davidson, P., "The Language of Internet Memes," The social media reader, ed. M. Mandiberg, New York: New York University Press 2012, 120-134.

Dawkins, R., Saatchi \& Saatchi New Directors' Showcase, Cannes, 2013. https://www.youtube.com/watch?v=GFn-ixX9edg

Dawkins, R., The selfish gene, 30 ${ }^{\text {th }}$ anniversary ed., Oxford: Oxford University Press, 2006 [1976].

Dynel, M., "'I Has Seen Image Macros!' Advice Animal Memes as Visual-Verbal Jokes," International Journal of Communication 10, 2016, 660. 
Kolman, L. et al., "Cross-cultural differences in Central Europe," Journal of Managerial Psychology 18.1, 2003, doi:10.1108/02683940310459600.

Krajewska-Kułak, E. et al., "Current view of the traditional superstitions in general population of Podlaskie province. Preliminary study," Progress in Health Sciences 1.2, 2011, 76-83.

Kuiper, N. A., et al., "Humor Styles and the Intolerance of Uncertainty Model of Generalized Anxiety," Europe's Journal of Psychology 10. 3, 2014, doi:10.5964/ejop.v10i3.752.

Piekot, T., "Pictorial representation of idioms in Internet humour," Estonia and Poland: Creativity and tradition in cultural communication, L. Laineste, D. Brzozowska and W. Chłopicki (eds.), Tartu: ELM Scholarly Press; Eesti Kirjandusmuuseumi Teaduskirjastus, 2012.

Sztompka, P., "The ambivalence of social change. Triumph or trauma?,"WZB Discussion Paper: 00.001, 2000.

\section{Internet sources}

"Co oglądają Polacy" [What Poles are watching], portalmedialny.pl 16.01.06 http://mediafm.net/art/32076/co-ogladaja-polacy.html

http://memy.pl; http://demotywatory.pl/; http://fabrykamemow.pl/

http://www.nytimes.com/2013/12/18/us/harold-camping-radio-entrepreneur-who-predicted-worlds-end-dies-at-92.html?_r=0 